\title{
"The street is ours". A comparative analysis of street trading, Covid-19 and new street geographies in Harare, Zimbabwe and Kisumu, Kenya
}

\author{
Richard Kiaka $^{1} \cdot$ Shiela Chikulo ${ }^{2} \cdot$ Sacha Slootheer $^{3} \cdot$ Paul Hebinck $^{4}$ (D) \\ Received: 25 November 2020 / Accepted: 8 March 2021 / Published online: 25 March 2021 \\ (C) The Author(s) 2021
}

\begin{abstract}
This collaborative and comparative paper deals with the impact of Covid-19 on the use and governance of public space and street trade in particular in two major African cities. The importance of street trading for urban food security and urban-based livelihoods is beyond dispute. Trading on the streets does, however, not occur in neutral or abstract spaces, but rather in livedin and contested spaces, governed by what is referred to as 'street geographies', evoking outbreaks of violence and repression. Vendors are subjected to the politics of municipalities and the state to modernize the socio-spatial ordering of the city and the urban food economy through restructuring, regulating, and restricting street vending. Street vendors are harassed, streets are swept clean, and hygiene standards imposed. We argue here that the everyday struggle for the street has intensified since and during the Covid-19 pandemic. Mobility and the use of urban space either being restricted by the city-state or being defended and opened up by street traders, is common to the situation in Harare and Kisumu. Covid-19, we pose, redefines, and creates 'new' street geographies. These geographies pivot on agency and creativity employed by street trade actors while navigating the lockdown measures imposed by state actors. Traders navigate the space or room for manoeuvre they create for themselves, but this space unfolds only temporarily, opens for a few only and closes for most of the street traders who become more uncertain and vulnerable than ever before, irrespective of whether they are licensed, paying rents for vending stalls to the city, or 'illegally' vending on the street.
\end{abstract}

Keywords Street trade $\cdot$ COVID-19 $\cdot$ Informality $\cdot$ Informalisation $\cdot$ Street geography $\cdot$ Urban restructuring

\section{Introduction}

In this paper, we assert that measures to contain the Covid-19 pandemic hugely impinge on the way public space in the urban domain is used. We focus specifically on what happens on the street as a component of public space. The street is

Paul Hebinck

Paul.Hebinck@wur.nl

1 Social Anthropology, Jaramogi Oginga Odinga University of Science and Technology, Bondo, Kenya

2 Sociology of Development and Change Group, Wageningen University and Research, Wageningen, Netherlands

3 International Development, Utrecht University, Utrecht, Netherlands

4 Sociology of Development and Change Group, Wageningen University, Wageningen, Netherlands beyond doubt an important resource that supports the livelihoods of substantial numbers of traders selling food in the street, consumers and their families. Covid-19 triggered lockdowns and curfews as well as measures to restructure markets and to regulate the street trade. These measures restrict the use of public space, providing in turn expanded opportunities for extracting bribes and harassment. The restrictions intensified and exacerbated the socio-spatial tensions and contestations over the use of public space that structurally occur in cities (Brown 2006; Lefebre 2001; Bryceson and Pots 2006). We analyse the impact of Covid-19 on the use of urban space and the trade in food in the streets in particular as processes that redefine existing geographies of the street and create new ones.

The urban governance before Covid-19 usually entailed the restructuring of public spaces. The relationships between street traders and urban policymakers have always been ambiguous and contentious. The mobility of street traders is regularly restricted and marketplaces and the flow of goods 
regulated through the setting of standards, often done in the name of addressing hygiene issues (Chikulo et al. 2020; Battersby and Watson 2019). The Covid-19 pandemic, however, introduced new governance instruments to intensify the urban restructuring through a series of interventions that derive their acceptability from a global consensus that preventing mass gatherings, reducing mobility, and imposing social distancing and hygiene standards are among the measures to be taken to prevent and contain the spread of Covid19 (McCloskey et al. 2020). For state and municipal authorities and politicians, containing Covid-19 became synonymous with implementing urban restructuring policies, legitimizing the demolishing of vending sites, and reorganizing of food markets. The execution of Covid-19 measures, blended with urban restructuring, boosted encounters that intensified the contestations, ambiguities, and struggles that take place in cities across the globe. Our analysis of the 'new' street geographies in cities like Harare and Kisumu shows that the contested nature of the city has become even more pronounced when the informality of the governance of public space and the informal economy was branded as responsible for the spread of Covid-19 because of the crowdedness and poor conditions of hygiene and sanitation. The violence exercised by the state, ${ }^{1}$ the everyday struggles faced, and the contesting of the repressive environment by street actors are distinctive for the 'new' street geographies.

We identify the contours of the new street geographies drawing on case material from Harare and Kisumu and examine the processes and manifestations of the Covid-19 measures that sharpen and deepen the contestations surrounding urban space that existed before the pandemic. The narratives we collected from newspapers and through interviews and observations in Harare and Kisumu analytically demarcate the contours of the new street geography: the everyday struggle for the street deepened during and since the Covid-19 pandemic, and the new street geography is loaded with agency. When the central wholesale markets Mbare Musika in Harare and Kibuye in Kisumu were closed and the pavements in the central business districts became off-limits to vendors due to the lockdown and the curfew, we note that the restrictions unlock adaptations and creative ways to deal with the repression. New vending sites are constructed; night trading, door-to-door selling, and car boot sales are amplified, attracting in turn actors that previously were not involved in street vending; new forms of trading emerged; all these can be taken as evidence for a new street geography. Harassing and extracting bribes from traders by the police and city controllers, and the demolishing of stalls by municipal authorities,

\footnotetext{
${ }^{1}$ Our meaning of violence derives from the work of Hannah Arendt (1970) who debates violence in association with the state. Violence is the means exercised by the state to exert its power over society. Violence, however, is not exclusively an instrument in the hands of the state.
}

city councils and politicians, while pushing their urban restructuring agendas, is also a property of the new street geography. The ambiguity of the new street geography is evidenced by the policemen extracting bribes from street traders, while they themselves purchase food on the street, by the trader paying bribes to be left alone, and a combination of repression and tolerance performed by municipal authorities and politicians while enforcing their image of the 'modern' city.

To illustrate and theorize the new street geography, we proceed by defining our methodological cornerstones of street geographies and what we mean by 'informal' and 'informality'. We also explain how we collected the data and which sources of data we consulted. The third section succinctly draws some comparisons between Kisumu and Harare to provide context for the analysis. The fourth section contains the core of the paper, which is where we order and present our data. We conclude with an interpretation of our data.

\section{The city as a contested space}

The Covid-19 pandemic and street trade does not occur in a vacuum, but in a space whose socio-material-spatial organisation is contested (Brown 2006; Lefebre 2001). Van Blerk (2013) coined the notion 'street geography' and Hanser (2016) 'street politics' to express that the city and its public spaces are lived-in-spaces. Space is but process and, as Harvey (2001) perceives it, constructed through practical everyday life activities:

"(T)hrough their daily activities and struggles, individuals and social groups create the social world of the city and, in doing so, create something common as a framework within which we all can dwell. While this culturally creative common cannot be destroyed through use, it can be degraded and banalized through excessive abuse." Harvey (2001: 103-104).

Spaces are constituted by the locally specific interactions amongst and between the human and non-human actors (Latour 2005). The non-human is not just captured by the traded commodities, the logistics, marketplaces, and the physical vending sites, but also includes the urban planning modalities and the multiple organisational and spatial ontologies. Events like the Covid-19 pandemic and resultant measures similarly are processes that (re)structure space. Many social actors use and manage public spaces. For our analysis, we make a distinction between street actors (i.e. street traders and consumers) and governance actors which include municipal planners, politicians, and street-level bureaucrats, such as members of the police and city controllers. The street-level bureaucrat is a subordinate of the municipality and at the 
forefront of the enforcing of the Covid-19 measures and the urban restructuring efforts of the state and municipalities. Ostrom (2010) unravels the functioning of markets as polycentrically organised. The methodological implication of this is that there is not one central organising entity or pre-established logic that orchestrates the use of public space, nor is there one single predominant hegemonic vision, but rather a plurality of discourses and practices (McFarlane 2011, 2012).

Street geographies derive their dynamics from the locally specific interlocking of 'structural' processes of what is understood as 'informality' and 'informalisation'. This conceptualisation of street geography similarly captures what Lefebre (2001) emphasizes in his analysis of city spaces as sites where the 'lived-in spaces of everyday life' of street actors encounter the abstracted and idealized symbols and images of governance actors that aim to (re)define the functions and activities suitable in designated spaces (see also Hanser 2016; Kamete and Lindell 2010; Öz and Eder 2012). Street geographies unfold as sites where the various discourses about the use of public space clash, generating, in turn, ambiguities, contestations, violent eruptions, and market demolitions. Street actors are, in these encounters, not to be seen as passive victims of state and politically orchestrated harassment and violence, but actors to which agency can be attributed, similar to the streetlevel bureaucrats that harass them or urban planners that interfere with traders' ontological organisation of urban space (Musoni 2010; de Pádua Carrieri et al. 2020; Long 2001).

It is our task to document the multiple encounters between street and governance actors, specifically the street-level bureaucrats. This entails recording the experiences and practices of street traders and bureaucrats in their (re)appropriating and (re)ordering of the street and other public spaces.

\subsection{Informality}

The city as a space where informality is predominant refers to situations of governance where laws, by-laws and regulations are renegotiated according to ever-changing power relations. Giving rise to (literally) violent face-to-face encounters between the street-level bureaucrat and street traders, these can potentially unfold in a temporary space of informal governance (Roy 2018; McFarlane 2012; Banks et al. 2020; Lata et al. 2019) or forms of (temporal) mutual engagement (Dragsted 2019; de Pádua Carrieri et al. 2020). Such spaces emerge, and are not fixed, but continuously contested and (re)negotiated by the social actors displaying their agency in their mutual encounters. This is the space were power and authority is displayed to carry out the urban restructuring project. Vendors operate in such a space by playing, what we refer to as, 'cat and mouse' or 'hide and seek' with the street-level bureaucrats who harass them to extract bribes as a display of their power over vendors (Rogerson 2016).
The state-directed attempts to formalise social and economic relationships manifest in the physical and spatial reorganization of the city, the urban food system and vending spaces. This generally plays out such that states and municipalities seek ways to increase the extraction of revenue from already economically hard-pressed informal entrepreneurs (Rogerson 2016; Lata et al. 2019).

\subsection{Informalisation}

The urban economy is informalizing, by which we mean the gradual transformation of an economy that increasingly revolves around economic activities that are relatively small scale and elude certain government requirements, such as registration, tax and social security obligations (Skinner 2008). The recurrent and deepening of the economic crises in Africa due to the structural adjustment programmes of the 1990s, collapsing industries, global competition, ill-fated social and economic reform programmes, population growth, climate change, and corruption have increased retrenchments and urban migration, forcing an increasing number of people to earn a living on the street through either trading food and non-food items or manufacturing (Tamukamoyo 2009; Potts 2011; Mujeyi et al. 2015). Typical for the informal sector is that it is increasingly and predominantly based on self-employment and relying on family resources (e.g. capital, labour) (Skinner 2016; Hart 1973; Sithole and Muguti 2018; Thebe and Ncube 2015; King 1977, 1996). The informal sector is, however, rather heterogeneous. There are informal entrepreneurs who ran a business which employs others. Cosmas, one of our respondents in Harare, owns more than seven pushcarts. Others, like Masimba in Harare, engage in undocumented contractual arrangements in food marketing whereby, for example, parts of market tables are sublet to others in exchange for a fee. Some businesses are registered and others are not. There is a consensus that the informal economy increasingly provides a substantial portion of employment and incomeearning opportunities for many (Brown et al. 2010; Potts 1995; Roever and Skinner 2016; Thebe and Ncube 2015; Battersby and Watson 2019; Meagher 2016). More importantly, perhaps, is that traders begin to claim their right to the city and the street by enacting street vending as a source of livelihood (Skinner 2008; Bénit-Gbaffou 2016). The tenacity of street vendors to claim their right to the city or the streets occurs while defending their livelihoods and that of their dependents, manifests in returning to the sites they were evicted from or developing and designing new vending spaces. This, in turn, triggers harassment and violence from the side of the authorities who do not share traders' ontological organization of markets and public spaces (de Pádua Carrieri et al. 2020). This is evident throughout the global South (Resnick 2019; Lata et al. 2019; Dragsted 2019). 


\subsection{The key argument: New street geographies}

'Informality' and 'informalisation' evoke different reactions in academia and networks of practitioners and experts. In development networks, the informal is praised as a sector that provides livelihood opportunities for many (King 1996; Bigsten et al. 2004; Battersby and Watson 2019; Benjamin et al. 2014). Informality is perceived as providing the flexibility that is needed to govern urban spaces that are shaped by a predominantly polycentrically organised informal economy (Goodfellow 2017; Roy 2018; Banks et al. 2020). In contrast, experts in public health, politicians and urban planners widely hold the 'informality' of public space governance and the 'informal' character of the economy (discursively framed by The World Economic Forum (2020) as 'social cohesion', 'social gatherings', and 'poor economic discipline'), together with malnutrition, a poor public health system and the double burden of a variety of diseases, responsible for the further spread of the Covid-19 virus (Lone and Ahmad 2020). The World Economic Forum marked responding to the concurrent health and poverty crisis as a 'unique' response; one which finds resonance with urban planners and politicians.

The negative perception surrounding informality is not new in Africa and cities like Harare and Kisumu. The illustrious Operation Murambatsvina (Potts 2006; Fontein 2009) implemented in Harare in 2005, during which stalls and street vending sites were demolished, was intended to purify urban spaces by driving out tsvina (filth) and was meant to be permanent (Kamete 2012). Similar operations were executed in Kisumu in 2003, 2005, 2006 and 2014 (Racaud 2018); in Blantyre and Lilongwe in Malawi with Operation Dongosolo (Clean-Up) (Riley 2014; Tonda and Kepe 2016), and Windhoek in Namibia with Operation Clean Sweep (Kazembe et al. 2019). Johannesburg experienced an Operation Clean Sweep (Bénit-Gbaffou 2016). The Statutory Instrument 77:2020 of Zimbabwe (Public Health (Covid-19 Prevention and Containment) Regulations 2020) specifically permits the demolition of any structure whose "occupation or use of which is likely to favor the spread or render more difficult the eradication of such disease." The informal economy is branded by state and municipal authorities as a Covid19 risk area because of the crowdedness and poor conditions of hygiene and sanitation. The following statement confirms this: "Harare City Council hereby informs all vendors trading at undesignated sites to immediately vacate such places as part of efforts to minimise human contact in the fight against the Corona Virus". ${ }^{2}$ Statements like these, which are clearly rooted in colonial discourses about hygiene standards and public safety (Morange 2015; Chigumira et al. 2018), provide

\footnotetext{
${ }^{2}$ Source: https://www.facebook.com/cohsunshinecity/posts/ 2907742892651406.
}

legitimacy for the authorities to demolish 'illegal' or informal vending stalls as has been observed in Harare and Kisumu.

The authorities expected that Covid-19 containment measures would reduce or even obliterate 'informality' and 'informalisation'. The measures, instead, boosted a street geography that is entangled in informality, providing continuity to an informal use of urban space shaped by ambiguous and contentious relationships between traders and the municipal authorities and street-level bureaucrats attempting to enforce their image of the 'modern' city (Rogerson 2016; Kamete and Lindell 2010; Hanser 2016). The street geography creates spaces, or room for manoeuvre, for some actors, but not for all in equal ways. This is what we found to be common in both Harare and Kisumu. The measures taken to contain Covid-19 redefine and create 'new' street geographies that hinge on the self-organising capacity of street actors while navigating the repressive environment and the expanded systematised bribes and harassment by governance actors.

\subsection{Data collection}

We build on research conducted in Harare (Chikulo et al. 2020; Slootheer 2020) and Kisumu before Covid-19. We extended and redid interviews and continued observations done during previous research cycles. We started with Mbare Musika in Harare and Kibuye in Kisumu. These are the central markets in both cities and are sites of political struggles and rivalry. We found that due to the temporal lockdown and curfew, some traders and consumers had shifted to other vending sites whose role in urban food security gained more importance and momentum due to the Covid-19 measures. Therefore, we visited market and vending sites in the suburbs, near bus terminals and shopping malls, and on the pavements in the Central Business Districts (CBD) in both cities. Some were newly created as a response to temporal closing of the central markets; others were revived; others were being resurrected after being demolished.

Insights from interviews were combined with observations of emerging situations on the street and in marketplaces. In Harare, Chikulo revisited Mbare Musika, the central wholesale market, and vending sites in the medium and high-density areas of the city (Ruwa, Tafara, and Mabvuku-Tafara). Slootheer reconnected with street vendors in the Harare CBD and the high-density areas in Harare (Crowborough, Eastview and Damofalls Park) and traders at the Mbudzi Roundabout. Our research assistants, Epiphania Garikayi and Daniel Chiukira with whom we worked before, interviewed 26 vendors for this paper; their experiences as inhabitants of high-density areas also enriched our insights. In Kisumu, Kiaka collected data with his colleagues Michael Oloko, Maureen Achieng and John Chweya, between December 2019, and October 2020, as part of a research project - Grassroots Financial Innovation for Inclusive 
Economic Growth - funded by the Danish International Development Agency. ${ }^{3}$ They interviewed 31 vendors operating in municipal markets, and markets in the informal settlements, CBD and major streets. Fieldwork in Kisumu prior to Covid-19 provided a useful ethnographic mirror for the changes that later took place. Hebinck provided analytical insights based on his longitudinal research experience in Kenya and Zimbabwe. We also relied on WhatsApp and telephone interviews conducted by research assistants and by ourselves to collect data because the lockdown and curfew prevented us from conducting large numbers of face-to-face interviews.

\section{Containing Covid-19 in Harare and Kisumu}

In March 2020, the Kenyan and Zimbabwean governments took measures to contain the spread of Covid-19. Movement of people and goods across borders was temporarily suspended; social distancing was imposed by temporarily banning social gatherings, including in markets; closure of all eateries that were deemed unhygienic and without handwashing facilities; a curfew was imposed from $7 \mathrm{pm}$ to $5 \mathrm{am}$ in Kisumu and from $3 \mathrm{pm}$ to 6 am in Harare, except for the transportation of essential goods and services such as food. The curfew was shortened in Kenya from $10 \mathrm{pm}$ to $4 \mathrm{am}$, in Zimbabwe, eventually, from $6 \mathrm{pm}$ to $6 \mathrm{am}$. The curfew and lockdown did not only target the central markets and CBD's but also vending sites in the settlements and high-density suburbs, such as Manyatta A and B in Kisumu and MabvukuTafara and Crowborough in Harare.

Mbare Musika was closed on March 30, 2020, and left thousands of farmers and traders stuck with perishable produce that was ready for sale. The government later recognized the centrality of Mbare Musika and relaxed the lockdown three weeks later to partially allow open agriculture markets, supposedly under strict rules to prevent the virus from spreading. ${ }^{4}$ In Kisumu, the governor ordered the closure of the Kibuye market on March 22, 2020. ${ }^{5}$ The order was received by traders with anger and protest. Traders complained of rotting foodstuffs because of losing their customers and delayed delivery of produce. Later, in June, Kibuye was demolished and bulldozed to make way for renovations. Traders complained and argued that the bulldozing added more pain to what was already inflicted by previous Covid-19 measures. They accused the municipality of using Covid-19 as an excuse to insidiously enforce the urban restructuring programme.

\footnotetext{
3 https://grassrootsfinancialinnovation.org/

${ }^{4}$ See https://www.herald.co.zw/farmers-count-lockdown-losses/

${ }^{5}$ See the Daily nation newspaper at https://nation.africa/kenya/counties/ kisumu/kisumu-market-closed-amid-coronavirus-fears-281500
}

\subsection{Harare and Kisumu's city spaces}

The urban economies in Kisumu and Harare have in common that they have been shaped by rather similar structural process. In the early 1990s, Kenya and Zimbabwe were subjected to a deepening of neoliberal market policies (known as structural adjustment programmes), which adversely affected local industrial growth (e.g. closure of textile factories), agriculture (e.g. the collapse of cotton farming) and employment in the East and Southern African region and their cities. Agriculture in Kenya's Lake Victoria region lost viability due to cheap imports from India and China (Mbithe et al. 2017). Zimbabwe suffered from ill-fated agrarian reforms and a resultant economic meltdown, which, in turn, made people migrate to the city, only to become and remain unemployed as industries collapsed (Chikulo et al. 2020). Since the 1990s, unemployment in Harare and Kisumu has been increasing, stimulating an expansion of the informal sector. Recent estimates indicate that at least $60 \%$ of Kisumu's population depends on the informal sector as a source of livelihood (Racaud 2018). The share of food purchased on the street is estimated to be about 75\% in Kisumu (Opiyo et al. 2018: 25; Racaud 2018) and $87 \%$ in Harare (Tawodzera et al. 2016). Street trade constitutes a major component of the informal sector in Kisumu (Steyn 2012) and Harare (Sithole and Muguti 2018; Chikulo et al. 2020). The exact number of street vendors operating in the city can only be estimated. Estimates for Kisumu range between 40,000-55,000 traders. ${ }^{6}$ The number of traders in Kibuye market fluctuates between about 7000 from Monday to Friday and 10,000 on Saturday. The number is said to increase to about 20,000 on Sundays. ${ }^{7}$ Harare counts 30,000 registered vendors, yet Matamanda et al. (2019) estimate that in 2017 at least 100,000 vendors were operating in the city, of which 20,000 were in the CBD. The vast number of unregistered traders implies that many of them operate 'illegally'.

\subsection{Restructuring urban spaces and resistance}

Chigumira et al. (2018: 146) in a study of Epworth, a periurban area near Harare, note the specifics of the politics of restructuring and the nature of urban planning in Zimbabwe: the by-laws and strategic plans emphasize formalization and regulation of trade, a focus incongruent with the largely informal nature of markets. These by-laws do little to facilitate informal food systems as they are still shaped by the colonial vision of what an ideal city should be (see also Matamanda 2020). The current spatial distribution of informal vending activities is thus viewed as 'disorderly and haphazard'. This is in sharp contrast to arguments in much of the urban

\footnotetext{
${ }^{6}$ Interview with Ian, at Arina Social Hall, Kisumu, 11.08.2020. See also Racaud (2018)

${ }^{7}$ Interview with Catherine and Ian, Kisumu, 13.08.2020.
} 
informality literature that stresses how informal activity is hardwired into models of the state to reduce cost, thereby directly and indirectly incentivizing informality (see also Mpofu 2016). Both the 'illegality' and the vast and growing numbers of street vendors motivates the state and municipal actors to restructure and modernize the city spaces. Restructuring the city space is considered important for health and food safety reasons because of fears of disease outbreaks (e.g. cholera). Restructuring the city follows a rather common pattern by relocating vendors from the public space to marginal locations with low pedestrian foot traffic and/or inadequate facilities (Roever 2016).

Operation Murambatsvina (Potts 2006; Fontein 2009) was carried out in Harare, before Covid-19, in May 2005. Stalls and street vending sites were demolished. Mbare Musika and other street trading sites were hard-hit. Traders could not return for more than a week to their stalls as the municipal and republic police officials destroyed structures around the highdensity suburbs and marketplace. Murambatsvina was, however, not just a reassertion of urban planning policies, but also an impulsive display of the ability of politicians to use state power (Fontein 2009). Life at the market gradually returned to 'normal' with strict measures to keep the market clean and allow only those with council registrations into the retail section (Musoni 2010). This situation triggered new forms of cooperation amongst and between the women traders (Chikulo et al. 2020) which allowed them to navigate the restructuring of the marketplace.

In Kisumu, a similar 'city cleaning' programme aims to replan the city by bringing down shacks and traders' stalls to make way for roads, public parking, a harbour and to improve health, sanitation and hygiene. In 2003, 2005, 2006, 2014, and 2019 several markets were demolished. The proposed construction of a Hawkers' Mall is counter to the logic and organisational ontology of the informalized food system, if only because its planned location is far removed from the usual consumers. After failed previous attempts, restructuring the Kibuye market is again on the county government's agenda. The plan is to renovate the market to accommodate the ever-increasing number of traders, provide space for essential facilities such as toilets, a car park, and modern market stalls. ${ }^{8}$ The micro-politics of the restructuring is embedded in local politics characterised by political rivalry and resistance. Traders resisted by filing a lawsuit against the county government for the lack of traders' participation and absence of satisfactory relocation plans. The lawsuit was unsuccessful. Faced with this resistance, the authorities have been careful in their approach of evicting traders from the market as the trader quoted below illustrates:

\footnotetext{
${ }^{8}$ See, for example, https://www.standardmedia.co.ke/nyanza/article/ 2001374467/kibuye-open-air-market-takes-a-sh479m-break
}

"You see after the fence was erected to separate the market and the road, the city manager came here in Kibuye and told us that the plan is to construct a car park and loading area. So, traders would move 30 metres away to create space. But we saw that that plan would dispossess many people of their livelihoods and space and negotiated with the City to allow us to move only 10 metres away. Then mama [city manager] came back and said that we could now move 20 meters and that was her last bargain. The money was ready, I think from the French Government, to build the parking area". 9

This consultative approach to smoothen the negotiations failed and a court order was given allowing the City to demolish stalls and evict traders from the space. However, the demolition and eviction were delayed because the City feared potential violent street protests by traders. The order to demolish the market was implemented after all.

\section{Covid-19 regulations and the new street geographies}

Our data and observations aptly illustrate the processes generated by Covid-19 measures and provide a good image of Harare and Kisumu's new street geographies which have emerged in the wake of the Covid-19 pandemic. The new street geography is an extension of previous processes of urban governance that generated contestations, protests, violence, and ambiguities. The contestations over the emerging geography deepened in the wake of Covid-19. This notably concerns the demolitions of so-called 'illegal structures' and the banning of 'illegal activities' that had increased in number. One of the ambiguities of the resultant new street geography is that the measures enlarged the room for manoeuvre for some actors to extract value from the street, either through trading or harassing and bribing, but certainly not for all in equal ways. This space unfolds only temporarily for some through a combination of repression, tolerance, mutual engagements, and interdependencies. Our analysis, however, also indicates that an unknown number of vendors run the danger of becoming excluded from the predominant informal economy. Their livelihoods will be more uncertain and vulnerable than ever before, irrespective of whether they are licensed, paying rents for vending stalls to the city, or 'illegally' vending on the street.

The following processes mark the salient and emergent properties of the new street geographies in both cities:

1. The urban politics of restructuring and the municipal power play has intensified. The visible manifestation of the

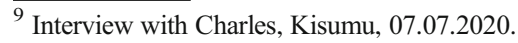


restructuring is the demolishing of markets which have increased with the implementation of Covid-19 measures. This includes demolishing with promises of relocation to sites with new infrastructure.

2. The harassing of traders by street-level bureaucrats in exchange for bribes has intensified.

3. Responding to their increased harassment vendors innovatively play 'cat and mouse' with street-level bureaucrats as.

4. Middlemen managed to continue importing through bribing and the forming of syndicates.

5. New vending sites were opened-up by traders after their original sites were demolished.

6. Livelihood adaptations and reorientations of business strategies emerge in the wake of the Covid-19 pandemic. These manifest themselves in new types of traders and traders reorienting their business model; this includes institutional adjustments to deal with cash flow problems.

7. Processes of exclusion and inclusion mark the new street geographies.

\subsection{Restructuring and municipal power play}

The politics of urban restructuring has intensified coinciding with Covid-19 measures. Newspapers and activists' reports refer to the destroying of market places in Harare as the government's 'demolition spree'. ${ }^{10}$ At the end of April 2020, the Harare City Council took advantage of the lockdown, ordered by the Ministry of Local Government and legitimised by the Statutory Instrument 77:2020 (Public Health (Covid-19 Prevention and Containment) Regulations 2020), to destroy thousands of roadside market stalls in many of Harare's highdensity suburbs. A City Council spokesperson said that the demolishing is 'in response to the growing need by Council to clean up the city and remove all illegal structures and curb all illegal activities ${ }^{11}$ Essential Services Director of the City of Harare, Addmore Nhekairo, stated in defence of the demolishing that the re-organization of the informal sector is meant to remove the "space barons"' from informal spaces. The vendors were relocated with promises to be accommodated in the shopping complex which is to be built. He says the Council is to take full charge of its spaces. ${ }^{13}$ In a message to the Harare residents, Council communicated that it:

\footnotetext{
$\overline{10}$ https://peoplesdispatch.org/2020/04/29/small-vendors-hard-hit-bygovernment-ordered-demolitions-in-zimbabwe/

${ }^{11}$ Council spokesperson Chideme quoted in the Daily News May 30, 2020: https://dailynews.co.zw/drama-as-council-destroys-structures/.

12 Space barons or slum lords are those that 'own' the infrastructure in the informal trading sectors. They collect rent from the informal traders. Council portrays them as exploiters of poor traders.

13 See https://www.facebook.com/cohsunshinecity/posts/ 2987276611364700 .
}

"advises that all members of the informal sector who have been trading on roadsides and at undesignated sites will be accommodated in proper structures postCovid19 period. Your Council is moving fast to prepare the Shawasha Market so that it accommodates all the informal sector members whose illegal structures have been removed". 14

Markets in Mbare, Chishawasha, Hatcliffe, Chitungwiza and Ruwa were demolished. Vendors mentioned that the council sent people and bulldozers ${ }^{15}$ to destroy their stalls, even in front of their own homes. Garai, who trades in Ruwa, said that:

"I used to have a small vending spot outside my gate, but the council destroyed it during the lockdown. I now sell in an open space where other vendors bring produce. We wish the council could build a proper market in Ruwa where we have facilities to lock up produce. ${ }^{16}$

The Mabvuku-Tafara high-density area in Harare similarly experienced market-demolitions in May 2020. An alternative 'formal' wholesale market was slowly rebuilt some weeks later by the City Council. The Council (only) fenced a portion of the market that was previously used by farmers to supply to vendors in the Mabvuku-Tafara area. Apart from a fence, there is no infrastructure. Our research assistants reported in early October 2020 that over 50 vendors were spreading their wares on plastic makeshift tables. Three lorries full of cabbages, three with chickens, and four pickup trucks with potatoes and onions had just arrived. Half of the vendors were selling different wares, such as vegetables, clothes, kitchenware, and firewood. The same situation was encountered at the Hatcliffe Market along Domboshawa Road. The Council just fenced a portion and charged fees for a site for farmers to put their wares and sell from. They display their produce on wooden crates. The reorganisation of the market place appears more of a revenue extraction measure, rather than a fullyfledged refurbishment to cater to the needs of suppliers, vendors, and customers.

Observations in Crowborough, another high-density area in Harare, reveal that some 50 vendors come to the Crowborough Shopping Centre during peak hours. A similar number operate from their homes near the shopping centre. The number has increased now, and those who had their structures destroyed at the shopping area and along the road began selling from home. Our research assistant who lived in the

\footnotetext{
14 See https://www.facebook.com/cohsunshinecity/posts/ 2967223160036712.

${ }^{15}$ See for instance https://www.youtube.com/watch?v=dKGDKSlj0zs

${ }^{16}$ Interview with Garai, at Ruwa Market, Harare, 01.10.2020.
} 
area reported that there are some 'die-hards' selling from the car park at the shopping centre.

Amidst the Covid-19 measures, the politics of market restructuring re-emerged in Kisumu. In May 2020, the county government started fencing Kibuye market in preparation for the reconstruction work. The works would include the opening of roads, improving sanitation, establishing the management office, and a fire management system. An official of the county government was quoted by a daily newspaper saying:

"The county is committed to improving the market to boost trading activities. We want traders to do business in a conducive environment". ${ }^{17}$

Traders protested, arguing that the closure of Kibuye due to Covid-19 was being used as a scapegoat by the government to allow them to proceed with the unpopular market restructuring project. These fears were strengthened by the observation that the temporary market spaces, Kosawo and the Moi Soccer Stadium, where the government had relocated traders, violated all pandemic regulations. ${ }^{18}$ Despite the resistance, the fencing proceeded and in June 2020, the government gave notice to traders with stalls in Kibuye to remove them to give way for market rehabilitation. The marketplace was bulldozed in June 2020, and the stalls were destroyed leading to massive loss of property by the traders. In response, traders unsuccessfully filed a lawsuit against the county government.

\subsection{Bribes and harassment}

The lockdown measures expanded the opportunity and space for the harassment of vendors and the imposition of bribes by street-level bureaucrats. Interviews and observations in Kisumu and Harare reveal that the harassment by authorities is a structural feature of the urban economy in Kisumu and Harare. Harassing has been amplified by and since the Covid19 measures. Intensifying and finding creative ways to extract (more) value from the street is one of the key emergent properties of the new street geography. Police presence by the vending sites located near the main bus termini is not a new feature since Covid-19. Police presence is rather random and erratic. In contrast, police presence is more constant in the CBD streets. This is where the 'die-hard' street vendors operate and where there are lots of customers. Sustained patrolling by the police over the main trading spaces in the CBD pays off for the policemen.

Experiences of three traders in the CBD of Harare pointed to repression and arbitrary enforcement of bribes by police

\footnotetext{
$\overline{17}$ https://www.the-star.co.ke/counties/nyanza/2020-05-26-kibuye-market-tobe-fenced-off-for-rehabilitation.

18 https://www.standardmedia.co.ke/nyanza/article/2001368701/new-marketviolates-all-pandemic-regulations
}

officers who confiscated their goods and harassed them with threats of imprisonment and charges until a bribe is paid. Masimba said:

"Police and municipal officers are still doing tight patrols making sure people follow Covid measures. During those patrols, they confiscate our produce with the excuse that we don't have the proper procedures to operate business (...). Yes, because of the curfew I had to finish early, at some point I was beaten by soldiers after failing to comply with curfew". ${ }^{19}$

Similarly, Joseph, a vendor operating from Mbare Musika, faced challenges in enforcing the Covid-19 regulations amongst his customers who came in large numbers. ${ }^{20}$ When the police spotted a gathering, they would throw teargas or beat the customers. So, he bribed them to make sure they stay away from his vending area. Similar testimonies were given by seven other vendors, vending in Crowborough, Mbare, Eastview and Ruwa.

In Kisumu, similarly, traders have to answer to various 'authorities' for protection. This is illustrated by the experience of Victoria, who traded eggs and fresh vegetables in Kibuye before her stall was destroyed. She changed vending locations twice before ending up near the Soccer Stadium in Kisumu, where the City authorities relocated vegetable traders. Her narrative confirms the pattern of bribing and harassment:

"They [the police] would arrest traders who violated rules like selling from Kibuye and other closed openair markets, and closing trade after curfew hours had clocked in. But they would also ask for bribes to let their victims free. So, traders realized that giving money to different officers on patrol was expensive. So, we became clever and our volunteer leaders decided to approach the top police officers for a confidential talk, I mean those who give junior officers orders to patrol and do surveillance. They agreed that traders would give them something small, you know, just little tea (bribe) in exchange for suspending patrols and police surveillance This worked for a while. But problems emerged when the City askaris kept coming. You know, they follow command from City security bosses and not the police boss. They harassed traders. Again and again, volunteer leaders went to see their bosses as well. Still some police officers would come on their own to demand bribes. So, we gave money to individual police officers, we gave money to the police bosses, we gave

\footnotetext{
${ }^{19}$ Interview with Masimba, a vendor by Fourth Street Bus Terminal, Harare CBD, 29.09.2020.

${ }^{20}$ Interview with Joseph, at Mbare Musika, Harare, 29.09.2020.
} 
money to city askaris and we gave money to the boss of city askaris. So, Covid-19 has been such a big loss for us traders, but a gain for police". 21

Brian, a vegetable trader, replying to a question about traders paying police officers as bribes so that they could remain in the markets to trade and not be harassed by the police, said:

"Oh, yes. That happened in Kibuye and Kondele. ${ }^{22}$ Some people who claimed to be leaders of traders went to the police boss. They spoke and agreed that they would collect money from traders and take them. Then, in exchange, the police boss would not send his officers to patrol in those areas. But soon traders realized that they were losing a lot of money. So many people had to be paid bribe. The police boss, the police officers, the city askaris and the boss of the city askaris". ${ }^{23}$

The interviews and observations also point out that it makes a difference for the bribe whether the police are in uniform and come in police trucks, or if they are in civilian clothing and on foot. The uniformed police are clearly sanctioned by the authorities. Policemen in civilian clothes operate seemingly on their own and charge fewer bribes but let the traders keep their goods. These are among the ambiguities of vending which also manifest in the mutual engagement Dragsted (2019) refers to. Traders and street-level bureaucrats need each other. We witnessed policemen buying on the street as much as the elites source their food from the street which is usually purchased by their domestic workers. Municipal officials purchase from pushcarts selling fruits and vegetables that strategically position themselves in the CBD and near government offices during lunchtime. Vendors in Harare, as opposed to those in Kisumu, confirmed in interviews that many of their regular customers are policemen and city officials. Some admitted that they strategically tried to appease policemen by giving goods on credit, sometimes for free, anticipating that in later raids they would benefit from these relationships. Sometimes these friendly relationships also involved being tipped when raids are being planned. The crackdown on vendors pays off both ways.

\subsection{Vendors play 'cat and mouse' with street level- bureaucrats}

Vendors play 'cat and mouse' or 'hide and seek' (Rogerson 2016) with the police. This demands some playing along with

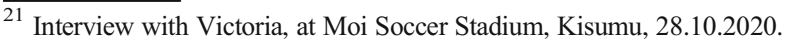

${ }^{22}$ Kondele is a suburb of Kisumu and the site of major riots end of March 2020 against the curfew.

${ }^{23}$ Interview with Brian, Kisumu, 28.10.2020.
}

the police and city controllers by bribing them to avoid open confrontations with the authorities. In essence bribing officials proactively creates some room for manoeuvre for traders to shift the terms of engagement to their advantage. Traders also strategically avoid confrontations with the street-level bureaucrats by trading only after their official working hours. Before Covid-19, street trading in the CBD of Harare and Kisumu would increase towards the end of the day, generally after $4 \mathrm{pm}$ or $5 \mathrm{pm}$. Vendors confirmed this in past interviews. ${ }^{24}$ A second element of the 'hide and seek' strategy is displaying smaller amounts of commodities during the day. This allows them to pack up their goods quickly when officials are spotted and to minimize losses when confiscations occur. During the Covid-19 lockdowns, a similar tactic was used as vendors would operate in the late-night hours to avoid confrontations. Grace, told us that,

"since police was not allowing [me] to move away from
home l used to go to the market, which is Mbare Musika,
by night around midnight while the police are sleeping
and by 2 am I [would] be back home. I just sleep for a
few minutes so in the morning people will be coming in
their numbers to buy. That's how I managed my busi-
ness during lockdown". 25

Traders do not always pay the bribes, however; some wait for the police to move on, before resuming their trading. Similarly, when the roadblocks are not manned, they resume trading. Interestingly, some traders noted that if traders do not pay their bribes, and when they cannot trade as they are being watched by the police, this offers opportunities for others to sell their commodities. This reduces competition they say. Some confessed to having made more money than before, despite the bribes they had to pay.

Vendors in Zimbabwe may file a request in Harare for a letter that exempts them from Covid-19 measures. These letters allow traders to transport and move products around. The letters are not easy to get and demand huge bribes to be paid. Some vendors even faked the letters and found a way to get someone to write a letter that looked official. Kudakwashe who is a small vegetable trader, however, found a way to circumvent the letters:

"I did not have a letter so I would go past these roadblocks on foot and then look for transport into town after passing the roadblocks. ${ }^{, 26}$

\footnotetext{
${ }^{24}$ See, for example, Slootheer 2020.

${ }^{25}$ Interview with Grace (via WhatsApp), a food vendor in Damofalls Park, Harare, 06.10.2020.

${ }^{26}$ Interview with Kudakwashe, a vendor by Tafara Shopping Centre, Harare, 05.10.2020.
} 
Ashley, a vegetable trader who was interviewed at the busy Mbudzi Roundabout site, stated:

"During the first-week business blossomed since everyone was panic buying and scared of scarcity, changed vending location from Mbare to Mbudzi because there was very tight security and many roadblocks to getting there. I used lorries and pickup trucks who travelled at night. I have an offer letter from the government, so used that as a mandatory letter to move around. Transport costs were very high, but I passed this on to customers. $" 27$

Masimba confessed that he wanted the show the authorities that he complies to the Covid-19 measures.

“(...)I limit people from touching the produce themselves; I sell produce in packages to avoid contamination; I bought a 20-litre bucket so customers can wash hands \& produce frequently. "28

Some vendors work closely together to avoid the police or the authorities. Tinotenda, trading in Ruwa Shopping Centre, pointed out that one strength we have as vendors at shopping centres is that:

"We keep each other informed. We also sell products for each other if one needs to go somewhere else and watch out for the police together.

\subsection{Middlemen syndicates}

Middlemen operate at the nodes of various networks and channels and play a central role in the street geography (Chikulo et al. 2020). They managed to continue to import their produce by paying substantial bribes. Even though the borders were closed as part of the Covid-19 measures, imported fruits from South Africa, Tanzania and Uganda were relatively widely available. At Mbare Musika, imported fruit (e.g. apples, pears, pineapples, nartjies and other fruits from South Africa) was sold at specific stalls. One stall owner explained that supermarkets and small private retailers come to buy fruit in bulk for resale in markets around Harare. The middlemen strategy was to form syndicates for sourcing produce from South Africa. They hired long haul trucks as these were the only trucks allowed on the road during the lockdown.

\footnotetext{
${ }^{27}$ Interview with Ashley, a vegetable vendor by Mbudzi Roundabout Market, Harare, 12.10. 2020.

${ }^{28}$ Interview with Masimba, a vendor by 4th Street Bus Terminal, Harare CBD, 29.09. 2020.

${ }^{29}$ Interview with Tinotenda, a fruits and vegetable trader by the Ruwa Shopping Centre, Harare, 02.10.2020.
}

There was a lot of bribing involved and they presented (often fake) letters at roadblocks to the police. This facilitated them staying in business. For those who had access to the transport letters and networks, the lockdown period provided a huge window of opportunity for making money. Joseph, who trades in the wholesale section of Mbare Musika, said he never stopped trading. He even recorded maximum sales:

“( ...) 'customers hoarded products like crazy fearing
the lockdown. I hired trucks to go to South Africa to
collect more products because the last week into the
21-day lockdown, the customers were not even worried
about the price they just bought. It was panic buying
(...). When the border closed, I changed my operations
and went to Nyanga [in the North East of Zimbabwe] to
source my merchandise. I bought my big lorry. From
Harare, I started carrying groceries to exchange with
produce (apples, bananas and avocado pears, potatoes)
from Nyanga. I certainly made money (...)., 30

\subsection{New vending sites}

With Mbare Musika temporarily closed and Kibuye bulldozed, and the streets cleared of traders, vendors expanded their street geography by identifying and creating alternative spaces for trading. Quite a few vendors we interacted with, moved to new or other sites. This demonstrates that vendors are creative and challenge the ordering of the city by the municipality. In most cases, the identification and construction of these trading sites (e.g. open spaces, pavements in the CBD) by the traders require agency and mutual connections. In a few situations, the new sites traders moved to had been designated by the municipalities.

\subsubsection{The 'Corona market' in Kisumu}

A day after the closure of Kibuye market and the ban of trade on the streets around Kibuye, traders went to search for an open public space. They found one - a road reserve - along the western bypass neighbouring Kondele, Manyatta and Arina informal settlements. There, they established a market that they called "Corona Market". The labelling underpins the resistance by street vendors to the closure of the market. While the Kibuye market and surrounding streets were militarised by the police, guarded, and patrolled, the traders started building makeshift stalls in what is now the 'Corona Market'. Vendors self-regulated the design of the marketplace and imposed their regulations (e.g. no touching of produce with hands, but rather using a long stick and wearing a face mask made by informal tailors). The vendors understood that the police would soon

\footnotetext{
${ }^{30}$ Interview with Joseph, at Mbare Musika, Harare, 29.09.2020.
} 
follow them to the 'Corona Market', forcing them to close the market and vacate the area where they had built their temporary makeshift stalls that are easy to demolish. Our observations show that at any time of the day around 650 vendors were selling their commodities at the 'Corona Market'; each of them claiming their space.

\subsubsection{Open-air markets in informal settlements}

Similarly, traders established small open-air markets in the informal settlements in Kisumu. With low per capita purchasing power, these highly populated informal settlements cumulatively provide a good customer base for the traders. The small quantities in which food is sold suits the low daily food budgets of nearly all families in these residential areas.

In Harare's high-density areas, the open-air markets selling small quantities of food are referred to as 'tsaona ${ }^{31}$, markets as they can serve the needs of any consumer who may suddenly run short of a food item while preparing meals. The widespread destruction of vending spaces rendered these dysfunctional during the lockdown. Following the relaxation of curfew measures, the open spaces soon filled with traders with temporal structures, especially during the end of the day (4 pm-7 pm).

\subsubsection{Door-to-door selling}

With vending sites being destroyed or made inaccessible due to the lockdown measures, some vendors decided to bring their products directly to their customers to make a living. One of these traders was Kudakwashe, who started selling from door-to-door in Harare:

"The lockdown affected me in both good and bad ways. The advantage was that on days that I could purchase stuff to sell it meant lots of income because most vendors had stopped selling in the first three weeks of the lockdown. I made a lot of money during those few days. However, after a while, it became harder to get stuff from around Mbare and other markets which forced me to stop. I also had to change my fixed vending location to mobile deliveries as a way of reaching customers who were stuck at home around Tafara and Mabvuku areas. It was not easy getting stuff during the lockdown. I could go for five days with nothing to sell (....). Customers who stay close to my house, just send me a WhatsApp message with their order and I can deliver to them. "32

\footnotetext{
$\overline{31}$ The term 'tsaona' means accident but in street lingo refers to a market that caters for urgent food items that can be bought in very small quantities and therefore often affordable to many people, including the cash strapped.

${ }^{32}$ Interview with Kudakwashe, by Tafara Shopping Centre, Harare, 05.10 .2020
}

Other vendors started to follow Kudakwashe's example of taking potential customers' phone numbers and calling them from time to time so see if they need anything delivered to their homes. There are customers, we were told, who ask for deliveries at their workplaces around Ruwa or their homes, "if the place is nearby, I can deliver to them", Garai stated. ${ }^{33}$

We also found vendors selling from home, during curfew between 8 am and 4:30 pm. Customers would come to their house to buy in the evening. Most use their phones to find new customers by posting daily WhatsApp status updates advertising the products they have for sale. Patience used to rent a council stall by the Crowborough Shopping Centre but now sells from her residence. She told us that she closes the gate when municipal police arrive, yet the curfew impacted her heavily. ${ }^{34}$ When customers do not move around because of the curfew, this means no business she says. Trading from door-to-door and on the streets, as well as in offices, has increased in Kisumu. To illustrate: Daisy has been a cooked food vendor since 2016. Before Covid-19, she sold cooked food under a large evergreen tree along a street lined with offices and other construction sites in Kisumu's Milimani area. During the closure of open-air markets and street food vending, Daisy closed her restaurant. Instead of quitting her business, she changed her tactics to continue trading, while evading law enforcers. She says:

"The stories of county officials never end. One time it is health certificate, another time it is them wanting us to pay revenues. One time it was the safety on the street and now it is a coronavirus. The whole day you just run hiding your items from the askaris, in the end, food is rotten, and you lose money. But the street is ours, and God has blessed me to make a living there.",35

Daisy's case illustrates vending as a common strategy through which 15 food vendors interviewed in Kisumu remodify and defend their territory in the urban space. Street traders are mobile, but the sites where they meet their customers daily can also be both fixed and mobile. Fixed in situations where customers are office workers or work on a construction site. The spaces are mobile when the customers change locality, and the traders need to follow them to new locations. This clearly remodifies urban spaces for the vendors such that they become elusive for government authorities who enforce Covid-19 containment measures. In doing so, vending, and the informality that constitutes it ensures the presence of food vendors on the street, and sustains their livelihoods.

\footnotetext{
$\overline{33}$ Interview with Garai, at Ruwa Market, Harare, 01.10.2020.

34 Interview with Patience, a fruits and vegetable vendor in Crowborough, Harare, 28.09.2020.

${ }^{35}$ Interview with Daisy, in Milimani, Kisumu, 22.07.2020.
} 


\subsection{Livelihood adaptations and reorientations of business strategies}

Covid-19 measures triggered a series of adaptations to either seek new opportunities to make a living or reorient the underlying business strategies, which sometimes implies making institutional changes. These adaptations were not so apparent before the pandemic as the Covid-19 inspired restrictions, such as the ban on the transportation of people and goods and the destruction of marketplaces, were absent. There is some evidence that a new type of trader is emerging in the wake of the Covid-19 crisis which would be evidence that the new street geography has attracted new players to the streets. Some of them lost their jobs and looked for opportunities in street trading. Godwin started vending in Eastview, Harare in June 2020 after losing his job at a construction company due to Covid-19:

"At first I was shy but now I am used to the whole
vending business because I have no other choice in this
tough economy (...). When the markets opened after the
initial lockdown, I decide to start selling fresh produce
and used $100 Z \mathrm{ZW}^{36}$ to buy stuff from Ruwa and order
bananas and apples. I had no vending stall, so I decided
to hire a pushcart to sell from. When I started making
enough money, I bought my own pushcart."37

In Crowborough in Harare, our research assistant spotted Munashe, who is a teacher at a local primary school. He is taking advantage of the lockdown to sell potatoes. Similarly, Tichaona, who used to work at the industrial sites, began vending after his company closed due to the deep economic crisis Zimbabwe suffers from. He is now selling onions from his sedan at the car parks near shopping centres. Tavonga, similarly, is a taxi-combi driver who started selling mixed vegetables from his combi without seats. He took the seats out of his combi to circumvent the ban on taxi combis. This ban also contributed to taxi-combi drivers 'repurposing' into mobile vending vehicles - selling anything, including sweet potatoes, potatoes, live chickens, groceries, and fresh vegetables, as a way of generating revenue amid the difficulties of registering under the ZUPCO ${ }^{38}$ facility. Few combis managed to get the ZUPCO 'franchise' or were hired to carry staff from different companies, hence taxi drivers shifted to vending.

\footnotetext{
${ }^{36}$ ZWL stands for the new Zimbabwean Dollar. Whereas till 2019 the currency was the US \$. After foreign exchange transactions were banned, the Real Time Gross Settlement (RTGS) dollar was introduced to solve the problem of physical cash shortages and inflation. This did not stop inflation and in November 2019, government introduced the 'new Zimbabwean dollar' (ZWL). The introduction of the ZWL did not end the record high inflation.

${ }^{37}$ Interview with Godwin, a pushcart vendor by Eastview Gazebo Shopping Centre, Harare, 03.10.2020

${ }^{38}$ ZUPCO (Zimbabwe United Passenger Company) is the parastatal transport network of Harare.
}

However, during the evenings, the same combis could ferry people and produce, especially in the high-density areas.

One other way of staying in business is changing what you sell or seeking other sources for your merchandise. The curfew and the lockdown limited what traders could (re)sell or inspired them to sell other goods or to seek other sites to sell; all this in an attempt to adapt to the Covid-19 containment measures. Traders, if possible, now prefer products that have a quick turnover ("move fast" as the traders say) so that these can be sold before the curfew time. We found vendors in Kisumu modifying and diversifying what they sell. During Covid-19 they had to begin to stock and sell non-cooked food (e.g. cereals, pulses, fruits, and fresh vegetables). Diversifying is key for traders. It reduces, they say, the risks that may befall a particular commodity. This is illustrated by Mama Talai.

"II]f I run the whole day away from askaris and fail to sell my ugali and beef stew, then I still have my dry beans and rice to hawk around that can give me income for my family. ${ }^{139}$

Cosmas used to sell, with his employees, fruits and vegetables from pushcarts in the CBD. When the CBD became a no-go area, he changed his operations from selling from pushcarts to using his pickup truck to sell, moving from one vending site to another and changing the products depending on demand. Lemons and sweet potatoes were on demand during the lockdown period, so he decided to stop selling the onions and oranges he was trading in before. ${ }^{40}$ Vimbai, who trades at Mbare Musika, for instance, said that she resumed trading in May 2020 because she needed to continue to make some money somehow, but now sells different commodities:

"However, instead of fresh produce, I was now selling soya chunk and kapenta [small, dried fish] as these were on-demand with residents living close to Mbare. ${ }^{\prime \prime 1}$

Mama Zahra illustrates this aspect of Covid-19:

"I used to have a makeshift restaurant, since 2017, along the main road leading to Kibuye market. But Covid-19 destroyed my makeshift [...]. I used the little money I had made to purchase dry maize to sell so that I can remain on the street and make a living. Since people had not harvested new maize for this year, I had customers for dry maize.",42

\footnotetext{
${ }^{39}$ Interview with Mama Talai, at 'Corona Market', Kisumu, 08.07.2020.

${ }^{40}$ Interview with Cosmas, at Ruwa Shopping Centre, Harare, 02.10.2020.

${ }^{41}$ Interview with Vimbai, at Mbare Wholesale Market, Harare, 18.10.2020.

${ }^{42}$ Interview with Mama Zahra, at 'Corona market', Kisumu, 07.07.2020.
} 
Sourcing from elsewhere is a common strategy to respond to the Covid-19 imposed restrictions. Masimba changed from sourcing directly from farmers in the Domboshawa areas, about $30 \mathrm{kms}$ outside Harare, to buying at Mbare Musika because the Covid-19 measures inhibited transport:

\section{"I had to personally go to farmers myself to source produce (...). Transport fares escalated each day be- cause of a few transportation methods. This also made time management very difficult especially if you would have gone to source produce from farmers; it would take hours to bring produce. ${ }^{\text {"43 }}$}

George, interviewed in the Harare CBD, mentioned that normally his produce comes from Honde Valley in the north-east of Zimbabwe and is then transported to Mbare Musika. Due to Covid-19, he says, he had to look for alternative sources. He now sells potatoes and vegetables from nearby farms, just outside Harare. $^{44}$

One of the significant impacts of Covid-19 for the street traders has been the lack of cash to pay for supplies and sustain their trade. The restriction of movement of people and goods within countries and across borders limited the supply and reduced their sales significantly. Similarly, the closure of markets and consequent evictions of traders led to only a few sales based on local supply networks. As Ian puts it during an interview:

\section{"a number of the traders, especially those selling fresh vegetables and fruits, were unable to sell their commod- ities as fast as they would in pre-pandemic rules." 45}

The traders cope with the resultant cash flow problems differently. Some are taking loans from groups constituted by traders to operate table banking (locally known as chamas) and rotational credits known as a merry-go-round. These table banking arrangements are organised by groups of traders who meet regularly to build a mutual fund through their savings. To cushion members from their immediate liquidity problem, chamas have relaxed their rules, including waiving the fines and extending the loan periods. Some chamas also ask their loanees to pay whatever amounts they get to cover their loans. An example of such flexibility is Lisa, who buys eggs from Uganda and sells in Kibuye. When cross border trade was suspended, she was stuck in Busia and used her earnings for upkeep in Uganda. Her business collapsed consequently. Her group members, upon hearing her predicament, granted her an

\footnotetext{
$\overline{43}$ Interview with Masimba, a vendor by 4th Street Bus Terminal, Harare CBD, 29.09.2020.

${ }^{44}$ Interview with George, a pushcart vendor near Copacabana Bus Terminal in Harare CBD, 29.09.2020.

${ }^{45}$ Interview with Ian (via telephone), a trader and Kibuye market leader, Kisumu, 09.08.2020.
}

emergency loan to enable her to survive in Busia, extended the loan period by six months, and waived all the fines. ${ }^{46}$ Similarly, chamas also organise merry-go-rounds as an important enhancer of liquidity flow for members. For the merry-go-round, each member contributes to a pool cash of an agreed amount during regular meetings. The money collected in a meeting is then given to one member. In a subsequent meeting, a different member is given until all the members have had their time to receive the money. Then, they begin again to following the pattern of rotation again. Members use the money to order supplies for their businesses or to do a project that they would have done with the income from their business.

Unlike in Kisumu, the typical savings groups (locally known as ma rounds) in Harare were (temporarily) suspended during the lockdown as people did not have the funds to contribute. But there were some exceptions, as Chiedza, a vendor from Eastview, explains:

"I never stopped contributing to the savings clubs, I have two groups, one from the church where we put in USD20 per month and we are five in that group. I also joined a club in my neighbourhood where we contribute USD5. I made sure I continued because this money always boosts my business. I used the money from my chicken sales or tailoring to pay for the club." 47

Another trader at Ruwa said that she had been selling from the same spot since 2018 and would participate in the ma rounds because they "help me get more produce and cushion me in difficult times". ${ }^{48}$ But when the lockdown happened, she had to maintain the rounds at all costs because she knew it was a way of survival. She, however, adjusted the money from 20 ZWL to $10 \mathrm{ZWL}$ per fortnight.

Cash flow problems resulting from the pandemic measures were also remedied by traders providing credit to others based on prior close social relationships. Vendors here, the story goes, are like a family:

"We share a lot of things like packaging and look out for each other when the council is bothering us. We still maintain good relationships with some farmers who know that we have been in business for a long time. That is how we get produce on credit and payback on the next visit to the market, often during the same week. ${ }^{, 49}$

\footnotetext{
${ }^{46}$ Interview with Rose, the secretary of Principle Chama in Kibuye, Kisumu, 08.07.2020.

${ }^{47}$ Interview with Chiedza, Eastview Gazebo Shopping Centre, Harare, 03.10.2020.

${ }^{48}$ Interview with Chipo, at Ruwa Market, Harare, 01.10.2020.

${ }^{49}$ Interview with Chipo, at Ruwa Market, Harare, 01.10.2020.
} 
Mr. Bananas, a farmer who sells from his pick-up truck in Eastview in Harare and supplements his own produce with purchases from nearby farmers, said that:

"Some farmers give me their products and allow me to pay after I sell. They are also trying to recover from the lockdown and are getting a bit flexible when we negotiate. I only do this with farmers who know me well though. ${ }^{50}$

\subsection{The future street geographies}

The street traders provided, in their interviews, a glimpse of the future of street trade after and beyond Covid-19, and of the undoubtedly ongoing attempt to restructure public space in the city. The data presented above paints a differentiated picture. Some managed and will continue to, somehow, navigate the space that is restructured by the Covid-19 restrictions on the mobility of goods and people and the reorganisation of space. The middlemen strived well; the new crop of entrepreneurs managed to carve out a piece of the trade; those that organised themselves in merry-go-round or table banking groups can sort out their financial flows. These traders are generally well resourced and organised in some form of collective.

Although many traders managed to adapt and create some room for manoeuvre, a substantial group of traders experienced the Covid-19 lockdowns negatively and threaten to be excluded from the street trade. Rotting fruits and vegetables, higher transport costs, mobility challenges, and money that normally would be invested in purchasing commodities now leaks as bribes. Increased operating costs have also diverted capital to other needs, such as school fees. The issue of mobility is key as most street vendors in Harare largely rely on public transport (the combis which were banned) and the failure by some to get the letters authorizing their movements rendered mobility (especially during the day) difficult. An unknown number of traders dropped out of the street trade business. Cecilia, for instance, was evicted from Kibuye. When she went to the newly created market, she found out that the new rules did not permit her to bring children under 11 years old to the market:

"I used to sell tomatoes in Kibuye. But I stopped when they moved people to the temporary market near the stadium. I cannot go there because I have a baby that I take care of and the City authorities said no babies are allowed there because babies will get corona. So, I

\footnotetext{
$\overline{50}$ Interview with $\mathrm{Mr}$. Bananas, a small-scale farmer from Goromonzi selling vegetables from his pick-up truck by the Eastview Gazebo Shopping Centre, Harare, 02.10.2020.
}

stopped trading. Now I am just in the house helping my chama to sell water. ${ }^{115}$

Some of those that have remained in business find, or will likely find, it difficult to operate in the post-Covid-19 urban economy. Even when restrictions are lifted, they will be confronted with various challenges that they previously were able to accommodate. The 'new structures' planned by the city officials, confine vendors to their stalls within the major bus termini in the CBD. These are also prepared elsewhere in the city, for example on the Coca Cola and Shawasha grounds. ${ }^{52}$ Traders mentioned that the fees are high, and they expect that these will rise. Masimba commented on the increase of table fees she pays to a fellow trade since the lockdown: “(...) table fees to operate formally have skyrocketed to unreasonable charges." ${ }^{\circ 3}$ Masimba's experience is supported by that of a fellow trader at Mbare, who said:

"Some stalls are still empty as you can see. This is because they were affected badly during the lockdown and had to leave after failing to pay the landlords of these stalls. The amount required per week is now 5 ZWL for a space that fits one pallet. A full stall can hold three pallets so the landlords are also trying to get as much as they can from their space., 54

Pauline, who resumed her vending in the CBD, told us that the monthly rent she is paying to the city council increased:

"No, rents are now different. We are now paying 1000 $Z W L$ per month, from $60 \mathrm{ZWL}$ before. We decided to make a payment plan with the city council so we are now dividing that money into four weeks. "55

Garai, who trades in Ruwa, describes how she and other traders make use of the newly created marketplace for farmers, where traders can source their produce. She explains how it works out to their advantage:

"After the lockdown, when regulations and curfews were finally relaxed, the council here at Ruwa opened a big market where farmers bring their produce. I think they just wanted to find a way of collecting money from farmers because there is nothing inside that fenced

\footnotetext{
${ }^{51}$ Interview with Cecilia, in Obunga Estate, Kisumu, 11.08.2020.

52 See: https://ucaz.org.zw/2020-06-12-harare-develops-new-market-sheltersfor-vendors/

${ }^{53}$ Interview with Masimba, a vendor by Fourth Street Bus Terminal, Harare CBD, 29.09.2020.

54 Interview with Tinashe, at Mbare Musika, Harare, 18.10.2020.

55 Interview with Pauline (via Whatsapp), a vendor by a bus terminal in Harare CBD, 24.09.2020.
} 
marketplace. It is an advantage for us because public transport is still a challenge (...). ${ }^{, 56}$

Another trader at Ruwa narrated that they were lucky here because the local authorities decided to fence the area for farmers to bring their produce to limit those going to Mbare Musika. ${ }^{57}$ Farmers from as far as Mutare and Honde Valley started coming to the market and selling potatoes, bananas, and sweet potatoes. The market still works, but operates from 5 am -11 am, implying that traders must rush there before doing anything else.

However, there is another side to this. Since the number of stalls that are promised to be built by municipalities on these market sites is or will be limited, only a few vendors can be accommodated. Those that used to operate from bus termini now seek refuge on the pavement downtown where police and municipal presence is more intense and where competition is fierce. Others choose to operate in the high-density areas where they face less police presence, yet equally intense competition. Garai pointed out to us:

"There are more vendors now, so competition is stiff. Those with personal cars easily go to the market and buy their stuff while people like myself are stuck in Ruwa. And now everyone is vending, you can see there are more than 100 people here selling produce because everyone wants to survive. But this is a lot of competition for me. All I can do is adding a variety of fresh fruits like oranges, bananas, pineapples, apples and some non-vegetable items." 58

Godwin associates the increased competition with the newcomers, like himself, resulting in reduced profits:

"I noticed that there are more people like myself who lost their jobs and started vending. There is a lot of competition in fresh produce vending, so we are forced to offer more for less just to sell before the produce goes bad., 59

\section{Discussion and conclusion}

The data presented warrants demarcating the new street geography that unfolds in the wake of the Covid-19 pandemic measures. Harare and Kisumu's urban food systems have in common that they are self-organised, informalized and

\footnotetext{
$\overline{56}$ Interview with Garai, at Ruwa Market, Harare, 01.10.2020.

${ }^{57}$ Interview with Chipo, at Ruwa Market, Harare, 01.10.2020.

58 Interview with Garai, at Ruwa Market, Harare, 01.10.2020.

${ }^{59}$ Interview with Godwin, a pushcart vendor by Eastview Gazebo Shopping Centre, Harare, 03.10.2020.
}

polycentric. The informalizing economy has, over time, considerably increased in density, intensity and size. It provides structure and expands the space for an urban informal food system that absorbs rural labour and commodities and provides livelihoods for the unemployed and for those who have become marginalised through critical events like the Covid-19 pandemic. The tensions and contestations surrounding the use of public space that existed before, remain, and have, in many situations, shifted to the newly created vending sites that are developed by the municipal authorities. The restructuring of public space through Covid-19 measures and the contestation around these produced a space where some, but certainly not all, thrive.

The lockdown and demolishing, the curfew, the bribes and violence, the cat and mouse, and the creativity and agency that is displayed by street traders moving to new vending sites mark the contours of the new street geography. This also includes vendors adapting their financial flows through various forms of cooperation and connections. Correspondingly, cleverly changing the range of commodities sold or produced is part of this. It is a geography that continuously hinges on ambiguous relationships between street traders and those that exercise formal political power, who can resort to instruments of sanctioned violence of the state, and those street-level bureaucrats that use unsanctioned, informal forms of power by extracting bribes and systemized harassment. The ongoing restructuring of the urban food system is not disconnected from these systematised bribes and harassment, but fits in a framework combining repression and tolerance that provide space for authorities and politicians to enforce their image of the 'modern' city (Rogerson 2016; Kamete and Lindell 2010; Matamanda 2020) and take advantage of the Covid-19 crisis to implement this. The self-organising capacity of traders, their agency and creativity while navigating the Covid-19 measures provides them with some room for resistance (Scott 2009), repressive tolerance (Kamete 2013b; Rogerson 2016) or mutual engagements (Dragsted 2019). This is what we also found to be common in both Harare and Kisumu.

A predominant characteristic of the street geography is the systematic bribes and harassment. The patterns we found to be common in Kisumu and Harare, both before and during the Covid-19 pandemic, are that:

1. the aggressive and repressive harassment of vendors by the police is seemingly approved by the government and municipal authorities. In Harare this is sanctioned by The Statutory Instrument 77:2020;

2 . the bribes are relatively randomly charged, vendors are not picked for their wealth or poverty, or for being formally registered by paying fees or unregistered. This matches the fluid, uncertain and divided regulatory environment surrounding street trading, which is a "complex mix of persecution, tolerance, regulation and promotion" (Rogerson 2016: p. 232); 
3. bribing is both exploitative and mutual. It is tempting to explain the harassing, demolishing and bribes as a oneway kind of an exploitative extraction of value from vendors by street-level bureaucrats. This would assume that the agency in the relationship lies with the street-level bureaucrat, who can exercise some kind of power to extract bribes from vendors. This is only partly the case and ignores that there is mutual engagement, indicating that interdependencies smoothen the relations between street traders and street-level bureaucrats. They mutually engage in what Dragsted (2019) frames as an economy where they seek valuable returns through investments in social relations. Musoni (2010) and Matamanda et al. (2019) reason that the bribing and harassing expose the more systemic problem of local officials in many African cities, whose low salaries make them continually susceptible to bribery, reinforcing corrupt practices (Skinner 2019). Charlotte, in an interview in January 2020, stated: "The police are hungry, they need it [what they confiscate] for themselves" 60

Repressive tolerance is how Rogerson (2016) and (Kamete 2013b) characterize the response of municipal authorities to street trading. Repressive tolerance is an "intervening" measure. It is an unofficial response that characterizes the authorities' handling of all types of informality (Kamete 2013a). It involves simply not acting, despite it going against the very grain of the urban order that the authorities foster. This tolerance is repressive as it signals that interventions may happen. Repressive actions of authorities are not new to vendors operating in cities like Harare and Kisumu. A reminder that street and food vending is "out of place". Dragsted (2019) understands this situation in a similar way but emphasizes that there is an element in this relationship between authorities and vendors of keeping the street economy intact. She explored regular payments of bribes by vendors to officers to argue that the aim is not to exclude vendors from the city. The perpetuating of a hostile policing environment that is rife with condemnations and tough conditions for traders, while (temporarily) taking little concrete action against them, rather serves to include them as central elements in an economy that produces policing and maintains certain political alliances. This creates room for manoeuvre for harassment to occur in and to extract revenues from seemingly 'formalized' rental constructions, but keeps the street trade intact, albeit in a different state and controlled order.

The restructuring by municipal authorities is a key dimension of the new street geography. Rogerson (2016) labels this as negative 'sanitising' responses, often rooted in the tradition of modernist urban planning. This signifies the disdain of municipal authorities and planners for the dynamics and

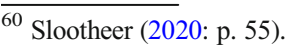

contribution of the informal urban food economy. The very nature of this is a political culture to regain control over the rapidly expanding informal sector in Harare and Kisumu. Their idealized version of the city legitimizes this strategy, one that does not resonate with the displayed spatial and material infrastructure constructed against all odds over time. The Covid-19 lockdowns have been used to drive these visions of the modern city. The current narrative justifies the destructions that occurred, as safe markets were needed to curb the spread of Covid-19. Instead, the large-scale destructions that occurred in Kisumu and Harare strikingly resemble past operations, such as Operation Murambatsvina, highlighting how the disdain towards the informal sector is being perpetuated.

State-administered urban planning, Roy (2018: 2243; 2009) argues, valorises and regularizes certain forms of informality and marginalizes, even criminalizes, others. The stateled attempts at modernizing and the controlling of social life at the marketplace and the street economy, through urban planning, generate severe tensions and conflicts and are fiercely resisted. The new street geography is harassing and being harassed, with intensifying repressive traits from the side of the authorities. In an economy like that of Harare and Kisumu and marketplaces like Mbare Musika and Kibuye, such policies seldom succeed as they lack inclusivity and appreciation of the ontological ordering that informality entails (Resnick 2019). The essence of this resistance lies in contrasting ontologies of the social and material environment for street vending (de Pádua Carrieri et al. 2020).

'The Street is Ours", as one trader once remarked in an interview in Harare, is an essential characteristic of the new geography of resistance, in which street-induced informality is one of the cornerstones. Wegerif and Hebinck (2016) and Wegerif (2020) coined the relationships between and amongst street traders as symbiotic and not necessarily as competitive. The symbiotic nature of their relationships provides actors with the means to defend their operations and their ordering of their vending sites. This is an essential trait of the new street geography, which deepens and strengthens the self-organizing capacity, negotiability, and resistance. This turns marketplaces and street vending into unpredictable operations and into places where actors grapple and negotiate for space and recognition. Opportunities in street trade appear fluid, although fraught with unwritten rules and expressions of power and influence. The fluidity that evolves in the marketing stands as a defence against state-led technocratic intrusions.

Our data also illustrates that the measures to contain Covid19 create space for many to navigate in, but with more beneficial outcomes for some than for others. The room for manoeuvre for street-level bureaucrats (e.g. police, municipal officials, politicians) to extract value from vendors, and to some degree also consumers, has increased. Some traders, notably middlemen, managed to increase their sales and make money from the lockdown by playing along. Others became 
marginalised and their futures as street traders eking out a living on the streets are in jeopardy. Most vendors are more uncertain and vulnerable than ever before, irrespective of whether they are licensed, paying rents for vending stalls to the city, or 'illegally' vending on the street. The street geography is a space that is unequally entered.

The focus on informality by centring on the self-organizing capacity of social actors in making and ordering their socialinstitutional-material environment is significant beyond the analysis of street vending only. Informality, and the struggle to maintain the order created through informality, constitutes an essential part of urban politics and governance (Pieterse 2013). The contesting of the restructuring of the urban environment is met with an alternative ontological ordering of space. Informality critically interrogates the widely shared (almost rational and teleological) notion, predominantly by city planners and policymakers, that the city (or the market, or the street or the economy) is progressively transforming from an informal (i.e. disorganized) to a modern (i.e. well organized) place (Kamete and Lindell 2010). Or that planners or the state take the dynamics generated by informality into account (Banks et al. 2020). In contrast, we argue that the use of public space, and the urban food system at large, is an emergent and fluid entity that is strongly nested in informality as a mode of economic organization and exchange. The situations that emerge are often openended, uncertain, and volatile and not immune to what is happening elsewhere in the (globalizing) economy. One structural feature of the street geography remains: the street continues to be a place for street vendors. Street vending remains a structural feature of cities, if only because the supermarkets and shopping malls, as projected in many urban planning models, cannot fully replace the street as a provider of food security. The street geography that unfolds creates new spaces of opportunity despite the inherent ambiguities, implying in turn that the street remains subject to an everyday struggle for the right to use public space ("the street is ours"). This struggle has been intensified during and since the Covid-19 pandemic. Policies that set out to control the use of urban space continue to be contested. The street geography continues to (re)create the struggle for the city, marketplaces, streets, and sidewalks.

Acknowledgements We thank the two anonymous reviewers and the associate editor for their insightful comments and suggestions for improvements. We also thank Epiphania Garikayi and Daniel Chiukira for collecting data for us in Harare, and Michael Oloko, Maureen Achieng and John Chweya for helping out in Kisumu.

\section{Declarations}

Conflict of interest The authors declared that they have no conflict of interest.

Open Access This article is licensed under a Creative Commons Attribution 4.0 International License, which permits use, sharing, adaptation, distribution and reproduction in any medium or format, as long as you give appropriate credit to the original author(s) and the source, provide a link to the Creative Commons licence, and indicate if changes were made. The images or other third party material in this article are included in the article's Creative Commons licence, unless indicated otherwise in a credit line to the material. If material is not included in the article's Creative Commons licence and your intended use is not permitted by statutory regulation or exceeds the permitted use, you will need to obtain permission directly from the copyright holder. To view a copy of this licence, visit http://creativecommons.org/licenses/by/4.0/.

\section{References}

Arendt, H. (1970). On violence: Houghton Mifflin Harcourt.

Banks, N., Lombard, M., \& Mitlin, D. (2020). Urban informality as a site of critical analysis. The Journal of Development Studies, 56(2), 223 238. https://doi.org/10.1080/00220388.2019.1577384.

Battersby, J., \& Watson, V. (Eds.). (2019). Urban food systems governance and poverty in African cities. London: Earthscan.

Bénit-Gbaffou, C. (2016). Do street traders have the 'right to the city'? The politics of street trader organisations in inner city Johannesburg, postoperation clean sweep. Third World Quarterly, 37(6), 1102-1129.

Benjamin, N., Beegle, K., Recanatini, F., \& Santini, M. (2014). Informal economy and the World Bank. Policy Research Working Paper. Washington, DC: World Bank.

Bigsten, A., Kimuyu, P., \& Lundvall, K. (2004). What to do with the informal sector? Development Policy Review, 22(6), 701-715.

Brown, A. (Ed.). (2006). Contested space: Street trading, public space, and livelihoods in developing cities. Ruby: ITDG Publishers.

Brown, A., Lyons, M., \& Dankoco, I. (2010). Street traders and the emerging spaces for urban voice and citizenship in African cities. Urban Studies, 47(3), 666-683. https://doi.org/10.1177/0042098009351187.

Bryceson, D., \& Pots, D. (Eds.). (2006). African urban economies: Searching for sources of sustainability. New York: Palgrave McMillan.

Chigumira, E., Tawodzera, G., Manjengwa, O., \& Mbengo, I. (2018). Governance of food systems in Epworth, Zimbabwe. In J. Battersby \& V. Watson (Eds.), Urban food systems governance and poverty in African cities (pp. 141-153). New York: Routledge.

Chikulo, S., Hebinck, P., \& Kinsey, B. (2020). 'Mbare musika is ours': An analysis of a fresh produce market in Zimbabwe. African Affairs, 119(476), 311-337. https://doi.org/10.1093/afraf/adaa003.

de Pádua Carrieri, A., Papadopoulos, D., Quaresma Júnior, E., \& da Silva, A. (2020). The ontology of resistance: Power, tactics and making do in the Vila Rubim market. Urban Studies, 1-19. https://doi.org/10.1177/0042098020912193.

Dragsted, B. (2019). Crackdown economics: Policing of hawkers in Nairobi as violent inclusion. Geoforum, 102, 69-75.

Fontein, J. (2009). Anticipating the tsunami: Rumours, planning and the arbitrary state in Zimbabwe. Africa, 79(3), 369-398.

Goodfellow, T. (2017). Seeing political settlements through the City: A Framework for Comparative Analysis of Urban Transformation. Development and Change, doi:https://doi.org/10.1111/dech.12361.

Hanser, A. (2016). Street politics: Street vendors and urban governance in China. The China Quarterly, 2016(226), 363-383.

Hart, K. (1973). Informal income opportunities and urban employment in Ghana. The Journal of Modern African Studies, 11(1), 61-89.

Harvey, D (2001). The Future of the Commons. Radical History Review(109 (winter)), doi:https://doi.org/10.1215/01636545-2010-017.

Kamete, A. (2012). Not exactly like the phoenix —-But rising all the same: Reconstructing displaced livelihoods in post-cleanup Harare. Environment and Planning D: Society and Space, 30(2), 243-261. 
Kamete, A. (2013a). Missing the point? Urban planning and the normalisation of 'pathological' spaces in southern Africa. Transactions. Institute of British Geographers, 38(4), 639-651.

Kamete, A. (2013b). On handling urban informality in southern Africa. Geografiska Annaler: Series B, Human Geography, 95(1), 17-31.

Kamete, A., \& Lindell, I. (2010). The politics of 'non-planning' interventions in African cities: Unravelling the international and local dimensions in Harare and Maputo. Journal of Southern African Studies, 36(4), 889912. https://doi.org/10.1080/03057070.2010.527643.

Kazembe, L., Nickanor, N., \& Crush, J. (2019). Informalized containment: Food markets and the governance of the informal food sector in Windhoek, Namibia. Environment and Urbanization, 31(2), 461480. https://doi.org/10.1177/0956247819867091.

King, K. (1977). The African artisan. Education and the informal sector in Kenya. London/New York: Heinemann/The Teachers College Press.

King, K. (1996). Jua Kali Kenya. In Change and development in an informal economy 1970-1995. London: James Currey.

Lata, L., Walters, P., \& Roitman, S. (2019). A marriage of convenience: Street vendors' everyday accommodation of power in Dhaka, Bangladesh. Cities, 84, 143-150. https://doi.org/10.1016/j.cities.2018.08.002.

Latour, B. (2005). Reassembling the social: An introduction to actornetwork-theory. Oxford: Oxford University Press.

Lefebre, H. (2001). The production of space. Oxford: Blackwell Publishing.

Lone, S., \& Ahmad, A. (2020). COVID-19 pandemic - An African perspective. Emerging Microbes \& Infections, 9(1), 1300-1308. https:// doi.org/10.1080/22221751.2020.1775132.

Long, N. (2001). Development sociology: Actor perspectives. London: Routledge.

Matamanda, A. (2020). Mugabe's urban legacy: A postcolonial perspective on urban development in Harare, Zimbabwe. Journal of Asian and African Studies, 0021909620943620.

Matamanda, A., Chirisa, I., Dzvimbo, M., \& Chinozvina, Q. (2019). The political economy of Zimbabwean urban informality since 2000 - A contemporary governance dilemma. Development Southern Africa, 37, 1-14. https://doi.org/10.1080/0376835X.2019.1698410.

Mbithe, P., Mwabu, G., \& Awiti, M. (2017). Impact of structural adjustment programs on agricultural sector growth in Kenya. Journal of Agricultural Policy, 2(1), 1-33.

McCloskey, B., Zumla, A., Ippolito, G., Blumberg, L., Arbon, P., Cicero, A., Endericks, T., Lim, P. L., Borodina, M., \& WHO Novel Coronavirus-19 Mass Gatherings Expert Group. (2020). Mass gathering events and reducing further global spread of COVID-19: A political and public health dilemma. The Lancet, 395(10230), 10961099. https://doi.org/10.1016/S0140-6736(20)30681-4

McFarlane, C. (2011). The city as assemblage: Dwelling and urban space. Environment and Planning D: Society and Space, 29(4), 649-671. https://doi.org/10.1068/d4710.

McFarlane, C. (2012). Rethinking informality: Politics, crisis, and the city. Planning Theory \& Practice, 13(1), 89-108. https://doi.org/ 10.1080/14649357.2012.649951.

Meagher, K. (2016). The scramble for Africans: Demography, globalisation and Africa's informal labour markets. The Journal of Development Studies, 52(4), 483-497. https://doi.org/10.1080/ 00220388.2015 .1126253$.

Morange, M. (2015). Street trade, neoliberalisation and the control of space: Nairobi's central Business District in the era of entrepreneurial urbanism. Journal of Eastern African Studies, 9(2), 247-269.

Mpofu, B. (2016). After the big clean-up. Street vendors, the informal economy and employment in Zimbabwe. In K. Hart \& J. Sharp (Eds.), People, money and power in the economic crisis (pp. 1941). Oxford: Berghahn.

Mujeyi, K., Mutambara, J., Siziba, S., Sadomba, W., \& Manyati, K. (2015). Entrepreneurial innovations for agricultural mechanisation in Zimbabwe: Evidence from an informal metal industry survey. African Journal of Science, Technology, Innovation and
Development, 7(4), 276-285. https://doi.org/10.1080/20421338. 2015.1082367.

Musoni, F. (2010). Operation Murambatsvina and the politics of street vendors in Zimbabwe. Journal of Southern African Studies, 36(2), 301-317.

Opiyo, P., Obange, N., Ogindo, H., \& Wagah, G. (2018). He characteristics, extent and drivers of urban food poverty in Kisumu, Kenya. In J. Battersby, \& V. Watson (Eds.), Consuming Urban Poverty Project (Vol. working paper no. 04). Cape Town: African Centre for Cities, University of Cape Town.

Ostrom, E. (2010). Beyond markets and states: Polycentric governance of complex economic systems. American Economic Review, 100, 408- 444.

Öz, Ö., \& Eder, M. (2012). Rendering Istanbul's periodic bazaars invisible: Reflections on urban transformation and contested space. International Journal of Urban and Regional Research, 36(2), 297-314.

Pieterse, D. (2013). City futures: Confronting the crisis of urban development. London: Zed Books Ltd..

Potts, D. (1995). Shall we go home? Increasing urban poverty in African cities and migration. The Geographical Journal, 161(3), 245-264.

Potts, D. (2006). 'Restoring Order'? Operation Murambatsvina and the urban crisis in Zimbabwe. Journal of Southern African Studies, 32(2), 273-291.

Potts, D. (2011). Making a livelihood in and beyond the African city: The experience of Zimbabwe. Africa, 81(4), 588-605.

Public Health (COVID-19 Prevention and Containment) Regulations 2020. Harare.

Racaud, S. (2018). Ambiguous resource:"informal" street trading in Kisumu, Kenya. Articulo-Journal of Urban Research(17-18), doi: https://journals.openedition.org/articulo/3702.

Resnick, D. (2019). The politics of crackdowns on Africa's informal vendors. Comparative Politics, 52(1), 21-51.

Riley, L. (2014). Operation Dongosolo and the geographies of urban poverty in Malawi. Journal of Southern African Studies, 40(3), 443-458. https://doi.org/10.1080/03057070.2014.913425.

Roever, S. (2016). Informal trade meets informal governance: Street vendors and legal reform in India, South Africa, and Peru. Cityscape, 18(1), 27-46.

Roever, S., \& Skinner, C. (2016). Street vendors and cities. Environment \& Urbanization, 28(2), 1-16. https://doi.org/10.1177/0956247816653898.

Rogerson, C. (2016). Responding to informality in urban Africa: Street trading in Harare, Zimbabwe. Urban Forum, 27(2), 229-251. https://doi.org/10.1007/s12132-016-9273-0.

Roy, A. (2018). The potency of the state: Logics of informality and subalternity. The Journal of Development Studies, 54(12), 22432246. https://doi.org/10.1080/00220388.2018.1460470.

Scott, J. (2009). The art of NOT being governed. an anarchistic history of upland South East Asia. New Haven: Yale University Press.

Sithole, A., \& Muguti, T. (2018). More than three decades of deprivation and impoverishment: The growth of the informal sector during the Mugabe era in Zimbabwe. In M. Mawere, N. Marongwe, \& F. Duri (Eds.), The end of an era? Robert Mugabe and a conflicting legacy (pp. 271-305). Bamenda: LangaaRPCIG.

Skinner, C. (2008). The struggle for the streets: Processes of exclusion and inclusion of street traders in Durban, South Africa. Development Southern Africa, 25(2), 227-242.

Skinner, C. (2016). Informal food retail in Africa: A review of evidence. In J. Battersby, \& V. Watson (Eds.). Cape Town: Consuming urban poverty project working paper no. 2. African Centre for Cities.

Skinner, C. (2019). Contributing yet excluded? In J. Battersby \& V. Watson (Eds.), Urban food systems governance and poverty in African cities (pp. 104-115). London: Earthscan.

Slootheer, S. (2020). Socio-spatial relations of food vending in Harare. An analysis of the social relations and spatial manifestations that affect food vendors in their contribution to food access to the lower income and food insecure residents of the city. Utrecht: University of Utrecht. 
Steyn, G. (2012). Modernity and informality — Conflicting forces shaping urban form in Kisumu, Kenya. International Journal for Housing Science and Its Applications, 36, 171-179.

Tamukamoyo, H. (2009). Survival in a collapsing economy: A case study of informal trading at a Zimbabwean flea market. Johannesburg: University of the Witwatersrand.

Tawodzera, G., Riley, L., \& Crush, J. (2016). The Return of Food: Poverty and Urban Food Security in Zimbabwe after the Crisis (Vol. urban food security series no. 22). Cape Town: African food security urban network.

The World Economic Forum (2020). Why Sub-Saharan Africa needs a unique response to COVID-19. Accessed Available from: https:// www.weforum.org/agenda/2020/03/why-sub-saharan-africa-needsaunique-response-to-covid-19/ 2020.

Thebe, P., \& Ncube, G. (2015). Street entrepreneurship in Zimbabwe: Survivalist or growth oriented?-a case of Bulawayo city Centre. International Journal of Development and Sustainability, 4(2), $126-144$.

Tonda, N., \& Kepe, T. (2016). Spaces of contention: Tension around street vendors' struggle for livelihoods and spatial justice in Lilongwe, Malawi. Urban Forum, 27(3), 297-309. https://doi.org/ 10.1007/s12132-016-9291-y.

Van Blerk, L. (2013). New street geographies: The impact of urban governance on the mobilities of Cape Town's street youth. Urban Studies, 50(3), 556-573.

Wegerif, M. (2020). "Informal" food traders and food security: Experiences from the Covid-19 response in South Africa. Food Security, 12, 797-800. https://doi.org/10.1007/s12571-020-01078-

Wegerif, M., \& Hebinck, P. (2016). The symbiotic food system: An 'alternative' Agri-food system already working at scale. Agriculture, 6(3), 40. https://doi.org/10.3390/agriculture6030040.

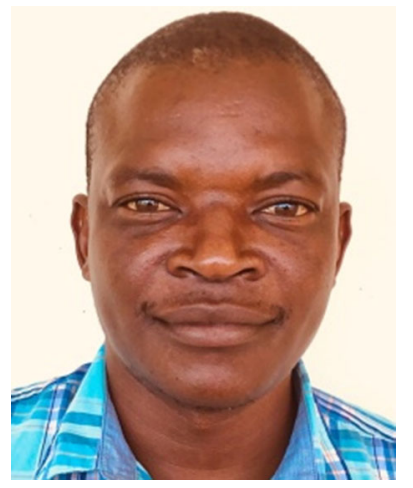

Richard Kiaka earned a $\mathrm{PhD}$ in Social Anthropology from the University of Hamburg. He is currently working as a Post-Doctoral Researcher at Jaramogi Oginga Odinga University of Science and Technology (JOOUST) in Kenya. His current research is focusing on the development and diffusion strategies of community currencies as complementary means of economic exchanges in informal settlements in Kenya. Richard also has research experience and interest in Community

Based Natural Resource Management in Namibia and Kenya.

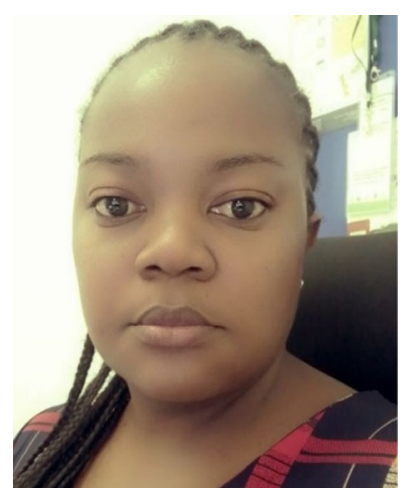

Shiela Chikulo is a PhD candidate in the Sociology of Development and Change Group at Wageningen University and Research. She is also a Communications Specialist at the International Maize and Wheat Improvement Center (CIMMYT) Southern Africa Regional Office. Her research interests are food systems, land and agrarian reform, rural-urban food markets, gender and impact evaluation of development assistance.

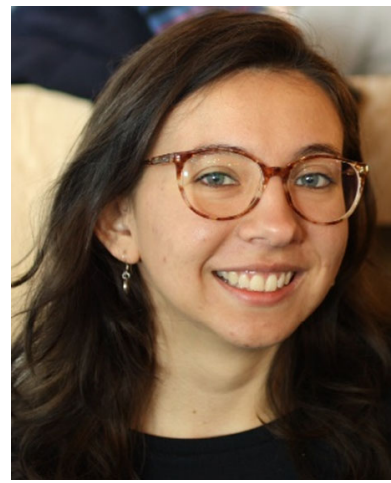

Sacha Slootheer is a recent graduate from the master Sustainable Development, specializing in International Development, at Utrecht University. She has a background in environmental studies through academic research and practical experience. For her master's thesis, she looked at the social relations and spatial manifestations of food vending in Harare, Zimbabwe. She has an interest in food systems, informal livelihoods, and gender.

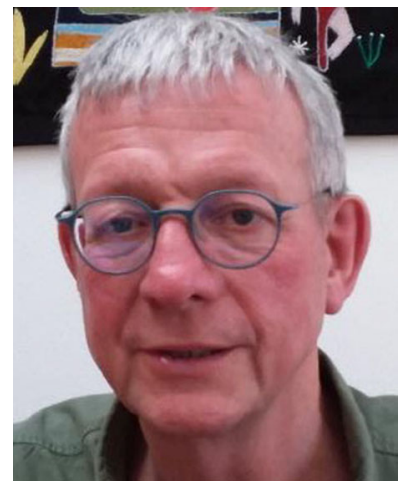

Paul Hebinck is an emeritus associate professor in the Sociology of Development and Change group at Wageningen University, The Netherlands. He is also Senior Research Associate, Department of Environmental Science, Rhodes University, Grahamstown, South Africa. Since the mid-1990s he has been doing longitudinal research in West Kenya, Zimbabwe and South Africa on issues and process related to land and the use of land. He published widely and acted as guest editor of a special issue on De/reagrarianisation processes for the Journal of Rural Studies (vol. 18, July 2018). 